UDC 911.9:620.92(262.54)

Nataliia Valeriyivna Popovych,

$\mathrm{PhD}$ (Geography), Associate Professor, Department of Physical Geography and Cartography,

V. N. Karazin Kharkiv National University, 4, Svobody Sq., Kharkiv, 61022, Ukraine, e-mail: n.popovych@physgeo.com, http://orcid.org/0000-0003-4968-6296;

Vilina Anatoliyivna Peresadko,

DSc (Geography), Professor, Department of Physical Geography and Cartography,

V. N. Karazin Kharkiv National University,

e-mail: vilinaperesadko@gmail.com, http://orcid.org/0000-0002-2439-2788;

Daria Romanivna Dzhym,

Master (Geography), Department of Physical Geography and Cartography,

V. N. Karazin Kharkiv National University,

e-mail: d.dzhim@physgeo.com,https://orcid.org/0000-0002-3823-1942

\title{
DEVELOPMENT OF OFFSHORE WIND ENERGY OF UKRAINE IN THE SEA OF AZOV: THE GEOGRAPHICAL ASPECT
}

\begin{abstract}
Н. В. Попович, В. А. Пересадько, Д. Р. Джим. РОЗВИТОК ОФНОРНОЇ ВІТРОЕНЕРГЕТИКИ УКРАЇНИ В АЗОВ-
СЬКОМУ МОРІ ГЕОГРАФІЧНИЙ АСПЕКТ. Статтю присвячено аналізу географічних аспектів розвитку офшорної вітроенергетики Украӥни в Азовському морі. Актуальність иієї теми зумовлена тим, щьо досвід розвинених країн світу переконливо доводить економічну та екологічну перевагу офшорних ВЕС, однак перспективи розвитку морської вітроенергетики в Чорному та Азовському морях украӥнськими науковиями розглядалися лише фрагментарно. До географічних передумов розвитку галузі в Азовському морі віднесено значні швидкості вітру (над деякими частинами моря сягають понад 9 м/с) та невеликі глибини акваторії (середня глибина Азовського моря - 7,5 м, а максимальна - не перевищує 14 м). Наведено результати аналізу вітроенергетичного потенціалу Азовського моря, виявлено тенденцію його зростання з заходу на схід. Встановлено, щцо акваторії північно-східного та північного узбережжя моря, де на висоті 200 м швидкість вітру досягає 9,3 м/с, мають максимальний потенціал для розвитку морської вітроенергетики. Приділено увагу методиці геоінформаційного моделювання розташування офшорних ВЕС з урахуванням обмежуючих факторів. Вона включає наступні етапи: створення шарів даних для кожного лімітуючого фактора та проведення операцій просторового аналізу; об 'єднання буферів в єдиний шар та накладання його на карти швидкостей вітру для акваторії, щзо досліджується; виокремлення ділянок різної міри придатності для будівництва морських вітроустановок. Практична реалізачія методики включала побудову карт, за якими оцінено придатність ділянок Азовського моря для розташування офшорних ВЕС на різних висотах. Виявлено збільшення площі ділянок, придатних для будівнищтва морських вітроустановок, з висотою $i$, відповідно, доцільність встановлення вітротурбін з вежею понад 100 м. Таким чином, існують географічні передумови розвитку офшорної вітроенергетики у прибережній зоні Азовського моря, але необхідні подальші інтердисциплінарні дослідження.
\end{abstract}

Ключові слова: географічний аспект, офшорна вітроенергетика, офшорна вітроелектростаниія, вітроенергетичний потенціал, Азовське море, Україна.

Н. В. Попович, В. А. Пересадько, Д. Р. Джим. РАЗВИТИЕ ОФФНОРНОЙ ВЕТРОЭНЕРГЕТИКИ УКРАИНЫ В АЗОВСКОМ МОРЕ: ГЕОГРАФИЧЕСКИЙ АСПЕКТ. Статья посвящена анализу географических аспектов развития оффиорной ветроэнергетики Украины в Азовском море. Актуальность этой темы обусловлена тем, что опыт развитых стран мира убедительно доказывает экономическое и экологическое преимущество оффшорных ВЭС, однако перспективы развития морской ветроэнергетики в Черном и Азовском морях украинскими учеными рассматривались лишь фрагментарно. К географическим предпосылкам развития отрасли в Азовском море отнесены значительные скорости ветра (над некоторыми частями моря достигают более 9 м/с) и небольшие глубины акватории (средняя глубина Азовского моря - 7,5 м, а максимальная - не превышает 14 м). Приведены результаты анализа ветроэнергетического потенциала Азовского моря, выявлена тендениия его возрастания с запада на восток. Установлено, что акватории северо-восточного и северного побережья моря, где на высоте 200 м скорость ветра достигает 9,3 м/с, имеют максимальный потенциал для развития морской ветроэнергетики. Уделено внимание методике геоинформационного моделирования расположения оффшорных ВЭС с учетом ограничивающих факторов. Она включает следующие этапы: создание слоёв данных для каждого лимитирующего фактора и проведение операций пространственного анализа; объединения буферов в единый слой и наложение его на карты скоростей ветра для исследуемой акватории; выделение участков разной степени пригодности для строительства морских ветроустановок. Практическая реализация методики включала построение карт, по которым оценена пригодность участков Азовского моря для размещчения оффшорных ВЭС на разных высотах. Выявлено увеличение площзади участков, пригодных для строительства морских ветроустановок, с высотой и, соответственно, иелесообразность установки ветротурбин с башней более 100 м. Таким образом, существуют географические предпосылки развития оффшорной ветроэнергетики в прибрежной зоне Азовского моря, но необходимы дальнейшие интердисциплинарные исследования.

Ключевые слова: географический аспект, оффиорная ветроэнергетика, оффшорная ветроэлектростаниия, ветроэнергетический потенциал, Азовское море, Украина.

Formulation of the problem. Currently in the world there is a question of natural resource depletion, which is a problem of economic, environmental and political nature. Ukraine's energy sector is currently import-dependent, and one of the sustainable development goals of the country to 2030 is "to ensure access to affordable, reliable, sustainable and modern energy for all" [19]. The implementation of this goal involves intensification of the use of own alternative energy resources, in particular, wind energy.

The wind potential of the mainland of our cou- 
ntry has been studied quite thoroughly, so now the interest lies in less studied water areas, which are promising for the development of offshore wind energy. The emergence of offshore wind farms (OWFs) in Ukraine could reduce the use of fossil fuels, which would improve the environmental situation and contribute to the decarbonisation of domestic energy. In addition, the development of renewable energy sources is one of the levers to increase the level of energy security, as stated in the Energy Strategy of Ukraine until 2035 [6].

The results of the study by the US National Renewable Energy Laboratory show that Ukraine can build OWFs with a total capacity of $146 \mathrm{GW}$ [25]. According to the Institute of Renewable Energy of the National Academy of the Sciences of Ukraine, the main areas for the development of the industry are The Dnieper River system of dams, Dzharilgatskaya Bay, Sivash Bay and the Sea of Azov [5].

The experience of developed countries convincingly proves the economic and environmental benefits of marine wind farms. The amount of initial investment into offshore wind facilities may exceed the same amount for onshore wind farms by 20 $50 \%$, but OWFs are more energy efficient than onshore [9]. Given the current energy problems, it is impractical to rule out the possibility of developing offshore wind energy in Ukraine. That is why the study considers the possibility of installing wind farms in the Sea of Azov, which is characterized by constant winds, and its small depth (up to $14 \mathrm{~m}$ ) is profitable for the installation of windmills. The coastal zones of the Sea of Azov can play a key role in the development of offshore wind energy in Ukraine.

Analysis of previous research and publications. Offshore wind energy is an industry that is supported by the governments of many countries. The most detailed studies to assess wind energy potential have been conducted for European countries that have already been developing offshore wind energy (the UK, Denmark, Germany, the Netherlands, Norway, Sweden) in the North and Baltic Seas.

However, this does not mean that other European countries are not studying this type of alternative energy. Currently, the wind power study is actively conducted in the coastal areas of the Atlantic Ocean. In particular, the energy potential of the coasts of Portugal and Galicia was estimated using the mesoscale atmospheric model WRF. Thus, the wind speed data (for the altitudes of 10 and $80 \mathrm{~m}$, the period 2009-2011), confirmed by the measurements of meteorological stations located in the regions, were obtained, and the potential of a single wind turbine was calculated. Based on this, it was concluded that the location of wind farms in these coastal areas is promising [31].

African countries are also considering the possibility of using water areas to accommodate OWFs. Thus, in the work of O. Adedipe and co-authors the suitability of different parts of Nigeria for the location of land and sea wind farms was assessed. Factors that inhibit the development of wind energy in the country were highlighted, including: inadequate level of research on the development of wind technologies; lack of government motivation to invest in the wind energy; misunderstanding of the benefits of this initiative by local people [21].

The development of alternative energy, reducing the country's economy dependence on the oil production are the strategic goals for Saudi Arabia. In particular, M. Mahdi and others analyzed the wind energy potential of the East Coast of the Red Sea. The authors substantiated and mapped 10 locations for the promising wind farms with a turbine capacity of 3.6 and $5 \mathrm{MW}$ [26].

One of the obstacles to Puerto Rico's economic development is the high cost of electricity, so scientists face the challenge of studying possibilities of using wind energy in the eastern region of the island. The country needs to install over $400 \mathrm{MW}$ of capacity from wind farms, and in 2015 the cost of electricity was calculated for different types of offshore turbines with a capacity of 2300, 3000 and $3600 \mathrm{~kW}[30]$.

N.A. Solidor in her work substantiated the project of creating a marine wind farm "Azov" with a capacity of $400 \mathrm{MW}$, which was proposed to be built on the shelf of the Sea of Azov and would be able to produce more than $2000 \mathrm{MWh}$ of capacity per year. This wind farm could be used to provide the nearest settlements and individual enterprises in the region with electricity [18].

Cartographic and geoinformation aspects of wind energy research were considered in the works of domestic [1,2,4,10] and foreign [15] scientists. In particular, O.O. Volkovaia, O.S. Tretyakov and I.G. Chervaniov proposed the method for indicating areas for wind turbines using geographic information systems (GIS) [4]. The system of cartographic works for the needs of alternative energy, in particular maps of conditions and factors influencing the development of wind energy, was considered by O.L. Agapova [1]. S.A. Velychko assessed, mapped and analyzed the possibility of building certain types of wind farms in the plains of Ukraine [2]. The method of compiling maps of favorable areas for the construction of solar and wind energy facilities was presented by Yu.Yu. Rafikova [15]. The study of A.N. Nekos and Ya.Ye. Molodan was devoted to using GIS for the needs of spatial planning of wind energy [10]. 
Prospects for the development of offshore wind energy in the Black Sea and the Sea of Azov were considered by Ukrainian scientists unsystematically. Thus, economic aspects of wind energy development in offshore zones of Ukraine, potential benefits and threats of OWFs were covered by V.V. Matveev and O.S. Shevtsova [8].

Unfortunately, the issue of offshore wind energy development in Ukraine currently remains virtually out of sight of geographers, although its resources are geographical, because they are mainly elements of the physical-geographical process [16]. The purpose of the research is to geographically analyze the wind energy potential of the Sea of Azov with subsequent assessment of the suitability of areas for the location of OWFs. In accordance with the purpose, the following tasks have been set:

1. to consider the geographical preconditions for the development of offshore wind energy in the Sea of Azov;

2. to analyze the energy potential of the Sea of Azov for the development of offshore wind energy in Ukraine;

3 . to carry out geoinformation modeling of limiting factors of Ukrainian OWFs location in the Sea of Azov;

4. to substantiate the promising areas for OWFs within the territorial waters of Ukraine in the Sea of Azov.

Methods and presentation of the study material. Renewable energy sources (RES) can be the key to solving global environmental problems and preventing the energy crisis. Concerns of the world community about climate change caused by greenhouse gas emissions are rapidly strengthening the position of alternative energy [20].

Today, amazing progress is demonstrated by a specific technology of renewable energy such as wind turbines. Due to improvement of their efficiency and reduction of investment costs, the use of wind energy in many cases is economically viable.

This is why wind energy is currently outpacing other renewable energy sectors, showing significant growth rates every year. A separate sector is offshore wind energy, which uses wind energy at power plants located at a distance of about $10 \mathrm{~km}$ to the shore, on shallow shelf and coastal areas.

According to the Global Atlas for Renewable Energy [23], the amount of electricity generated by OWFs has increased over the past 10 years. If in $20103,056 \mathrm{GW}$ of capacity was installed, in 2019 it became $28,155 \mathrm{GW}$, which is 9.2 times more than in 2010. 2019 turned out to be a record year for the industry, as 8 countries (China, the UK, Germany, Denmark, Belgium, Taiwan, Portugal and Japan) announced new marine installations [29]. According to Bloomberg New Energy Finance [24], by 2030 the installed capacity of the world's offshore wind energy will have increased to almost $115 \mathrm{GW}$ and China will become a world leader in the industry.

Offshore wind power most actively develops in countries where there is technological background, investment framework and the need to change wind turbines location due to a lack of area. Currently, the absolute leaders in the development of the industry are European countries. The European Wind Energy Association predicts an increase in the installed capacity of offshore wind energy in Europe to $70 \mathrm{GW}$ by 2030 [33].

Wind energy is and will be the most attractive sector of European energy for investors [7]. In 2020, European countries invested more than 26 billion euros in their own offshore projects, which allowed the construction of new wind turbines with a total capacity of almost 3 GW [33]. Thus, Denmark is the leader in installed offshore wind power per capita and tries to use all suitable for the installation of OWFs areas of the coastal zone [17]. Poland plans to build wind farms with a total capacity of $10 \mathrm{GW}$ in the Baltic Sea. This will help to meet the country's international obligations on the share of RES in gross energy consumption, which by 2030 should have become $21 \%$ [28]. In the UK, a tender for the lease of sea areas for OWFs with a total capacity of $8 \mathrm{GW}$ was completed in February 2021 [27].

Today, Ukraine is taking the first steps to offshore wind energy: domestic offshore projects are only under development. That is why it is extremely important to study the preconditions and limiting factors of industry development.

One of the main criteria for selecting OWFs location is the average annual wind speed. The amount of electricity that can be obtained depends on the strength and stability of the wind flow. Modern wind turbines generate electricity at wind speeds from $3 \mathrm{~m} / \mathrm{s}$ (minimum) to $25 \mathrm{~m} / \mathrm{s}$ (maximum). Wind turbines are profitable provided that the average annual wind speed for a certain area is not less than 6 $\mathrm{m} / \mathrm{s}$, otherwise the location of wind farms is irrational and unprofitable [13]. Wind speeds tend to increase with an altitude, so most wind turbines have tall towers.

Coastal regions of Ukraine throughout the year are characterized by wind speeds over $5 \mathrm{~m} / \mathrm{s}$, and over some areas of the Sea of Azov the wind speed reaches $9 \mathrm{~m} / \mathrm{s}$, which makes these areas the most promising for the use of wind energy [11]. If we consider only the wind speed, almost the entire water area of the Sea of Azov can be used for building OWFs on platforms.

The depth of the water area and the distance to shore are also important factors for the selection of construction sites for offshore wind turbines. Taking into account economic criteria (cost of energy com- 
munications, foundations and installation of underwater wind turbines), wind farms installed at a depth of not more than $35 \mathrm{~m}$ and at a distance not exceeding $45 \mathrm{~km}$ to shore are considered profitable. For wind turbines located in the coastal waters of Europe, the average depth is $27 \mathrm{~m}$, and the average distance to shore is about $43 \mathrm{~km}$ [18].

The average depth of the Sea of Azov is $7.5 \mathrm{~m}$, and the maximum depth does not exceed $14 \mathrm{~m}$. In general, the most promising are shallow territorial sea waters off the coast of mainland Ukraine, but for more thorough conclusions the wind energy potential of the water area has been estimated according to the following algorithm:

1. collection of data on the average long-term wind speed;

2. creation of wind speed surfaces;

3. linear interpolation;

4. calculation of the potential capacity of a single wind turbine.

1. Data on the average annual wind speed in the Sea of Azov were collected from the Global Atlas for Renewable Energy [23]. It provides information about the wind regime at an altitude of 50, 100, 200 m.

The attribute table included data on wind speed at 344 points within the Sea of Azov and coastal areas (Table 1). As a result, a data grid, which makes it possible to generalize the interpolation model of wind speed, was formed.

Wind speed at different altitudes (the fragment)

Table 1

\begin{tabular}{|l|c|c|c|c|c|}
\hline \multirow{2}{*}{$\begin{array}{l}\text { Point } \\
\text { No. }\end{array}$} & \multicolumn{2}{|c|}{ Coordinates of points } & \multicolumn{3}{|c|}{ Wind speed at different altitudes $(\mathrm{m} / \mathrm{s})$} \\
\cline { 2 - 6 } & Latitude (N) & Longitude (E) & $50 \mathrm{~m}$ & $100 \mathrm{~m}$ & $200 \mathrm{~m}$ \\
\hline 113 & $45^{\circ} 00^{\prime}$ & $36^{\circ} 24^{\prime}$ & 7.4 & 7.4 & 7.5 \\
\hline 114 & $45^{\circ} 12^{\prime}$ & $36^{\circ} 24^{\prime}$ & 6.9 & 7.3 & 8 \\
\hline 115 & $45^{\circ} 24^{\prime}$ & $36^{\circ} 24^{\prime}$ & 5.9 & 6.6 & 8 \\
\hline 116 & $45^{\circ} 36^{\prime}$ & $36^{\circ} 24^{\prime}$ & 7.8 & 7.8 & 8 \\
\hline 117 & $45^{\circ} 48^{\prime}$ & $36^{\circ} 24^{\prime}$ & 7.8 & 7.8 & 7.8 \\
\hline 118 & $46^{\circ} 00^{\prime}$ & $36^{\circ} 24^{\prime}$ & 7.7 & 7.9 & 8 \\
\hline 119 & $46^{\circ} 12^{\prime}$ & $36^{\circ} 24^{\prime}$ & 7.9 & 7.9 & 8 \\
\hline 120 & $46^{\circ} 24^{\prime}$ & $36^{\circ} 24^{\prime}$ & 7.9 & 7.9 & 8 \\
\hline 121 & $46^{\circ} 36^{\prime}$ & $36^{\circ} 24^{\prime}$ & 8 & 8 & 8.3 \\
\hline 122 & $46^{\circ} 48^{\prime}$ & $36^{\circ} 24^{\prime}$ & 6.1 & 6.9 & 8.4 \\
\hline 123 & $47^{\circ} 00^{\prime}$ & $36^{\circ} 24^{\prime}$ & 6 & 6.7 & 8.2 \\
\hline 124 & $47^{\circ} 12^{\prime}$ & $36^{\circ} 24^{\prime}$ & 6.2 & 7 & 8.5 \\
\hline
\end{tabular}

2. Modeling of wind speed surfaces was carried out in ArcGIS using the Spline tool. It minimizes the overall curvature of the surface, resulting in a smoothed surface that passes through the specified points. In our opinion, such a model correctly reflects the trend of wind speed distribution over the water area [22].

3 . On the basis of a point layer with data, isolines were generated to determine the contours of the areas of the Sea of Azov with the highest wind speeds. For the final formation of wind speed surfaces, it was necessary to create linear 2D objects based on previously saved attribute data. For this purpose 2 tools were used:

- Raster to TIN - to convert a raster model into a TIN model;

- Surface Contour - to obtain the contours of areas with certain wind speeds.

4. The next stage was to calculate the potential capacity of a single wind turbine $(\mathrm{P})$, which can be installed at a certain point in the water area. The cal- culations were performed according to the formula [14]:

$\mathrm{P}=\xi \cdot \pi \cdot \mathrm{R}^{2} \cdot 0.5 \cdot \mathrm{V}^{3} \cdot \rho \cdot \eta \mathrm{red} \cdot \eta$ gen

where:

$\xi$ - wind energy utilization factor (for highspeed windmills reaches $0.4-0.5$ );

$\mathrm{R}$ - rotor radius;

$\mathrm{V}$ - air flow rate;

$\rho$ - air density;

$\eta$ red-efficiency of the reducer;

$\eta$ gen - efficiency of the generator.

The advantages of the method of estimating wind energy potential, which is based on this formula, are simplicity of calculations, the availability of a set of initial data, as well as a fairly high accuracy of the results.

For our calculations, we used the parameters of the largest turbine installed in the offshore zone which is Vestas 164-9.5 MW (Denmark): rotor radius $-80 \mathrm{~m}$, power $-9.5 \mathrm{MW}$, hub height $-105 / 140 \mathrm{~m}$.

Thus, for point 113 with a wind speed of 7.4 
$\mathrm{m} / \mathrm{s}$ at an altitude of $50 \mathrm{~m}$ (Table 1 ), the equation is as follows:

$$
\mathrm{P}=\left(0.45 \cdot 3.14 \cdot 80^{2} \cdot 0.5 \cdot 7.4^{3} \cdot 1.25 \cdot 0.9 \cdot\right.
$$
$0.85)=1.752 \mathrm{MW}$

To calculate the potential amount of generated electricity, it was necessary to multiply the calculated capacity by the number of hours per year:
$1.752 \cdot 24 \cdot 365 / 1000=15,35 \mathrm{GWh} /$ year

Similarly, the potential electricity generation at each point was calculated (Table 2). The obtained data demonstrate the distribution of energy that can potentially be generated in the Sea of Azov, but in accordance with the purpose of our study, it is the territorial waters of Ukraine that are of interest.

Table 2

Potential electricity generation at different altitudes (the fragment)

\begin{tabular}{|l|c|c|c|c|c|}
\hline \multirow{2}{*}{$\begin{array}{l}\text { Point } \\
\text { No. }\end{array}$} & \multicolumn{2}{|c|}{ Coordinates of points } & \multicolumn{3}{|c|}{$\begin{array}{c}\text { Potential electricity generation } \\
\text { at different altitudes (GWh/year) }\end{array}$} \\
\cline { 2 - 6 } & Latitude (N) & Longitude (E) & $50 \mathrm{~m}$ & $100 \mathrm{~m}$ & $200 \mathrm{~m}$ \\
\hline 113 & $45^{\circ} 00^{\prime}$ & $36^{\circ} 24^{\prime}$ & 15.35 & 15.35 & 15.98 \\
\hline 114 & $45^{\circ} 12^{\prime}$ & $36^{\circ} 24^{\prime}$ & 12.44 & 14.73 & 19.39 \\
\hline 115 & $45^{\circ} 24^{\prime}$ & $36^{\circ} 24^{\prime}$ & 7.78 & 10.89 & 19.39 \\
\hline 116 & $45^{\circ} 36^{\prime}$ & $36^{\circ} 24^{\prime}$ & 17.97 & 17.97 & 19.39 \\
\hline 117 & $45^{\circ} 48^{\prime}$ & $36^{\circ} 24^{\prime}$ & 17.97 & 17.97 & 17.97 \\
\hline 118 & $46^{\circ} 00^{\prime}$ & $36^{\circ} 24^{\prime}$ & 17.29 & 18.67 & 19.39 \\
\hline 119 & $46^{\circ} 12^{\prime}$ & $36^{\circ} 24^{\prime}$ & 18.67 & 18.67 & 19.39 \\
\hline 120 & $46^{\circ} 24^{\prime}$ & $36^{\circ} 24^{\prime}$ & 18.67 & 18.67 & 19.39 \\
\hline 121 & $46^{\circ} 36^{\prime}$ & $36^{\circ} 24^{\prime}$ & 19.39 & 19.39 & 21.66 \\
\hline 122 & $46^{\circ} 48^{\prime}$ & $36^{\circ} 24^{\prime}$ & 8.60 & 12.44 & 22.45 \\
\hline 123 & $47^{\circ} 00^{\prime}$ & $36^{\circ} 24^{\prime}$ & 8.18 & 11.39 & 20.88 \\
\hline 124 & $47^{\circ} 12^{\prime}$ & $36^{\circ} 24^{\prime}$ & 9.03 & 12.99 & 23.26 \\
\hline
\end{tabular}

After considering the average annual wind speed at altitudes of 50,100, $200 \mathrm{~m}$, the analysis of wind energy potential of the coastal zone of the Sea of Azov was carried out. As a result, there were identified and mapped: areas with wind speeds from 3 to $6 \mathrm{~m} / \mathrm{s}$ - classified as unfavorable for development of offshore wind energy, from 6 to $8 \mathrm{~m} / \mathrm{s}$ - as partially favorable, and areas with wind speeds more than $8 \mathrm{~m} / \mathrm{s}$ - as the most favorable.

According to the maps, for installations with a tower height of $50 \mathrm{~m}$, the water zone with maximum wind speeds $(8.1-9 \mathrm{~m} / \mathrm{s})$ stretches along the northern coast of the Sea of Azov and has an area of 3353 $\mathrm{km}^{2}$. As the wind indicators become more stable with an altitude, the sector with the most favorable wind speeds at an altitude of $100 \mathrm{~m}$ has a larger area which is $3562 \mathrm{~km}^{2}$. At an altitude of $200 \mathrm{~m}$, the promising zone increases almost 2 times - up to $6544 \mathrm{~km}^{2}$ and is located almost along the entire coastline, occupying the territorial waters of Ukraine (Fig. 1).

The calculated indicators of the potential of the generated electricity at an altitude of $50 \mathrm{~m}$ vary from 1.8 to $26.7 \mathrm{GWh} /$ year. At an altitude of $100 \mathrm{~m}$, the minimum value increases to $5.0 \mathrm{GWh} /$ year, but the maximum decreases to $24.9 \mathrm{GWh} /$ year. Finally, at an altitude of $200 \mathrm{~m}$, there is a general trend of growth of the studied indicators, which directly de- pend on the wind speed, which at this altitude varies from 6.5 to $9.3 \mathrm{~m} / \mathrm{s}$. Indicators of potential electricity generated at this altitude range from 9.4 to $30.3 \mathrm{GWh} /$ year (Fig. 2).

These data can be used by designers of wind energy facilities as a basis for determining the optimal power of wind turbines and the type of energy (mechanical or electrical) for a particular area of the sea. However, our analysis would seem incomplete without modeling of the limiting factors of Ukraine's OWFs in the Sea of Azov.

Compared to traditional power plants, offshore wind farms are quite environmentally friendly, but there are some negative impacts of their operation, including: noise pollution, which interferes with the proper functioning of electrical appliances on aircraft and ships, decrease of the recreational area, deterioration of the marine environment. The visual impact of wind turbines should also be considered.

The development of wind energy projects, including offshore ones, involves the analysis of the impact of a potential wind turbine on the environment, the assessment of limiting factors. Such restrictions can be defined both at the legislative level (for example, the Water Code of Ukraine restricts building near water bodies [3]) and at the recommendation level (there are no specific legal restrictions on building wind farms near forests, but it 


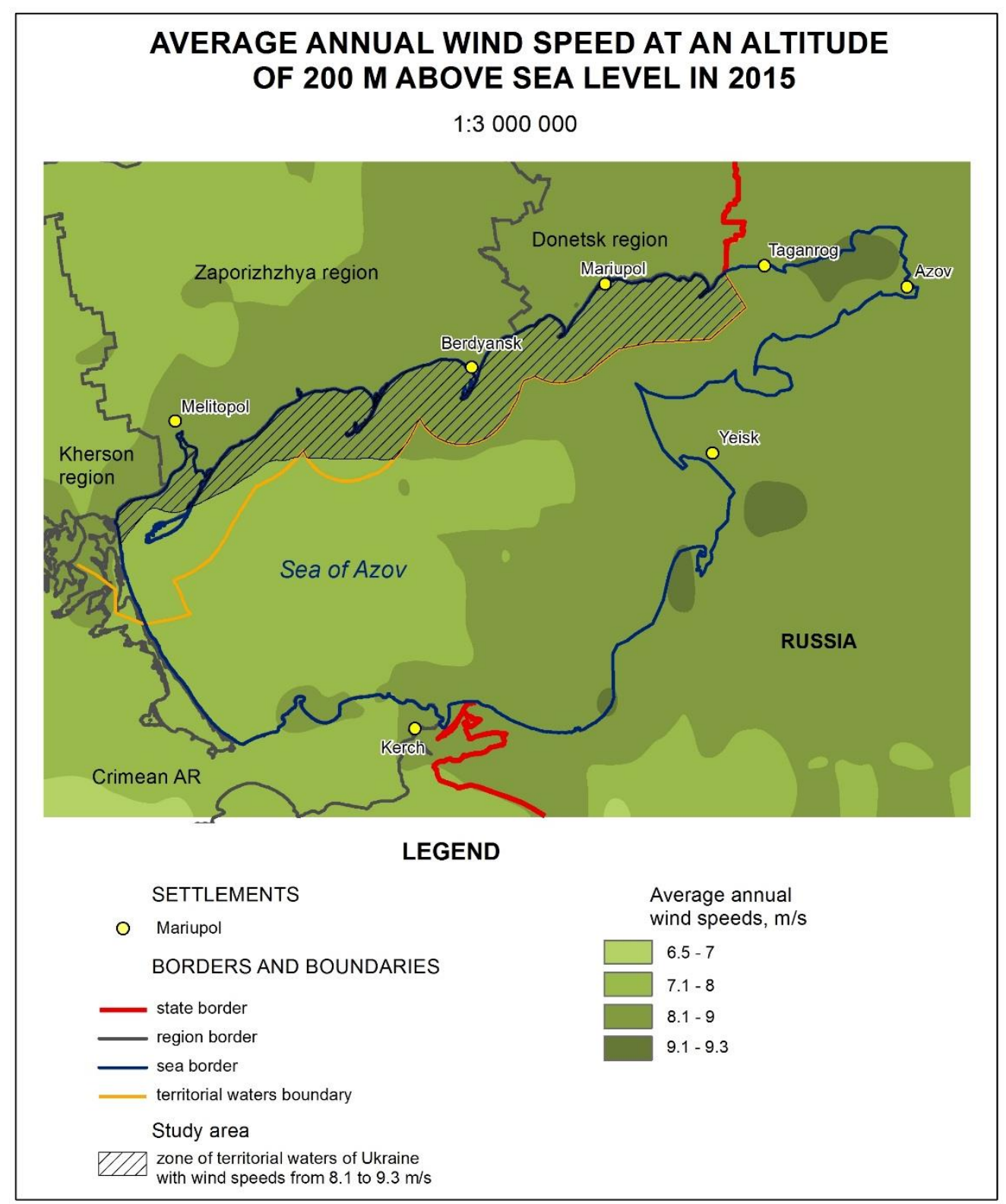

Fig. 1. The average annual wind speed at an altitude of $200 \mathrm{~m}$ above sea level [12] (scale changed)

is better to place windmills at a certain distance from them). The experience of developed countries shows that the installation of wind turbines can be prohibited due to a number of facilities, such as settlements and airports, water and engineering objects, forests and protected areas, military facilities.

Substantiation of expediency of offshore wind energy development requires a whole complex of scientific research taking into account economic, social and ecological factors. Cartographic and geoinformation modeling methods are effective for spatial optimization of wind energy facilities [10]. Fig. 3 demonstrates the GIS-based algorithm for selecting optimum location of OWFs, taking into account a set of limiting factors.

Geoinformation modeling has been performed in ArcGIS in three stages. The first stage was the analysis of the source information, "buffering" of limiting factors and the construction of buffer zones. As wind turbines can only be installed in the country's territorial waters, which are limited to 12 nautical miles (approximately $20 \mathrm{~km}$ ) to the shore, most of the Sea of Azov was already removed from further analysis. To correctly remove the water areas that, according to the law, do not belong to the territorial waters of Ukraine, parallel to the shoreline of the Sea of Azov a buffer zone of $20 \mathrm{~km}$ wide was identified. It was done with the help of the Buffer tool. The algorithm of this tool is well known: from each vertex of the object (in our case it is the turning points of the shoreline) the buffer offset is calculated, and the polygon of 20-kilometer zone is drawn from the extreme points to the shore. In this way, the first limited sea area was identified. The next limit- 


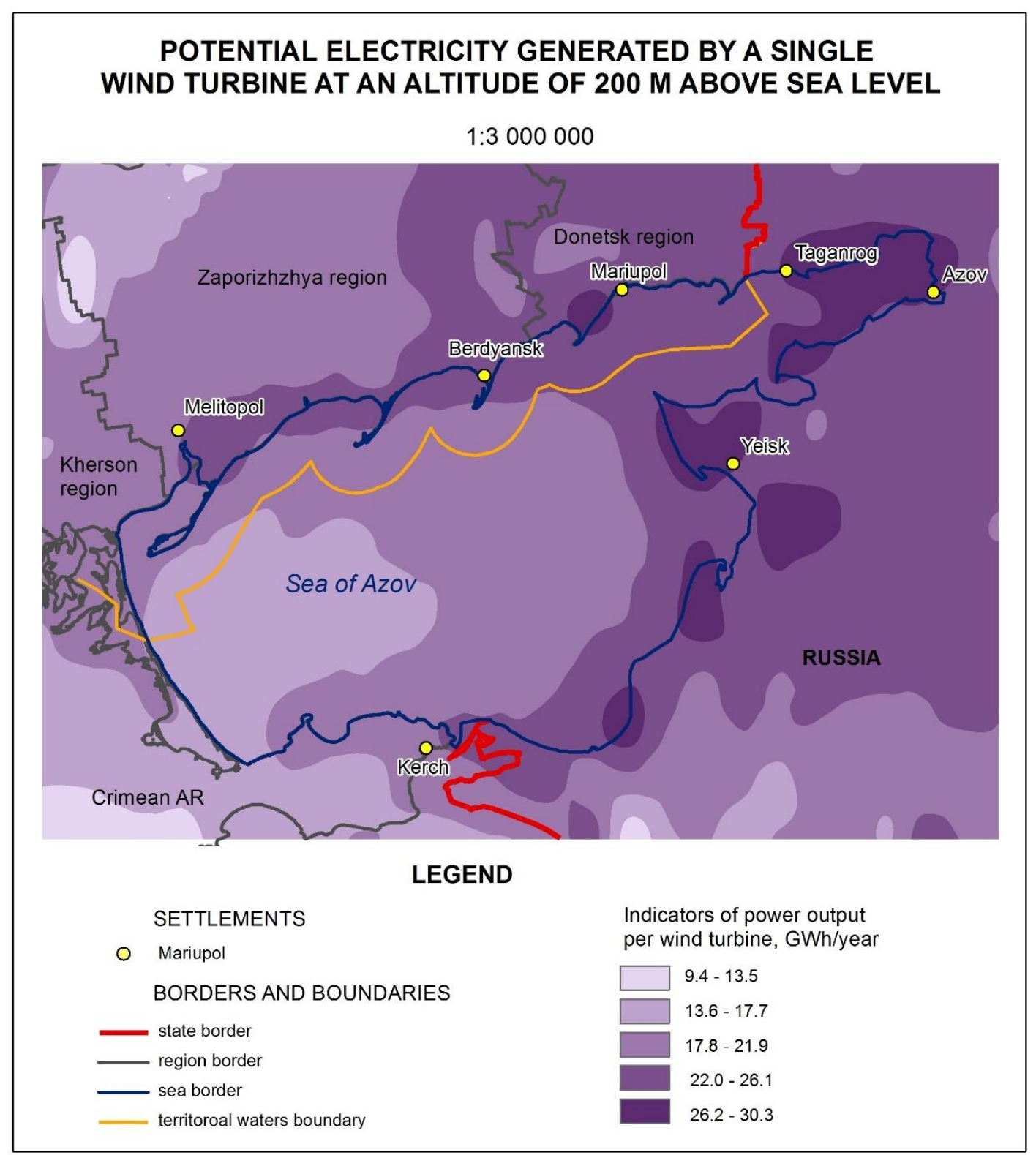

Fig. 2. Potential electricity generated by a single wind turbine at an altitude of $200 \mathrm{~m}$ above sea level [12] (scale changed)

ing factors for the installation of wind farms were protected areas, settlements in the coastal zone and existing airports. Spatial analysis operations were also performed for each of these elements.

To correctly determine the buffer zones of nature reserves of local or national importance within the territorial waters of Ukraine there were used maps of the Sea of Azov and OpenStreetMap. After digitization of each object of the Natural Reserve Fund in vector layers, they were given the attributive characteristics of the width of the protective strip: $500 \mathrm{~m}$ - for objects of local importance, and 1 $\mathrm{km}$ - for those of national importance. The result was the layers with polygonal objects of the Natural Reserve Fund.

The next step of buffering was the establishment of buffer zones of settlements located along the coastline of the Sea of Azov. Distances from settlements to wind farms were calculated based on generally accepted in Europe parameters: offshore wind turbines should be located at a minimum distance of $4 \mathrm{~km}$ to cities with a population of more than 250,000 people, and $750 \mathrm{~m}$ - to settlements with a smaller population.

The last limiting factor considered in our study for the coastal zone of the Sea of Azov was the airports in Mariupol and Berdyansk. It is believed that the width of the buffer zone of the airport should be at least $20 \mathrm{~km}$, as wind farms can create obstacles (sometimes catastrophic) for aircraft of different classes. Thus, a layer of protection zone of $20 \mathrm{~km}$ was created for each airport.

The second stage was to combine the obtained buffers into one layer and to combine this layer with 


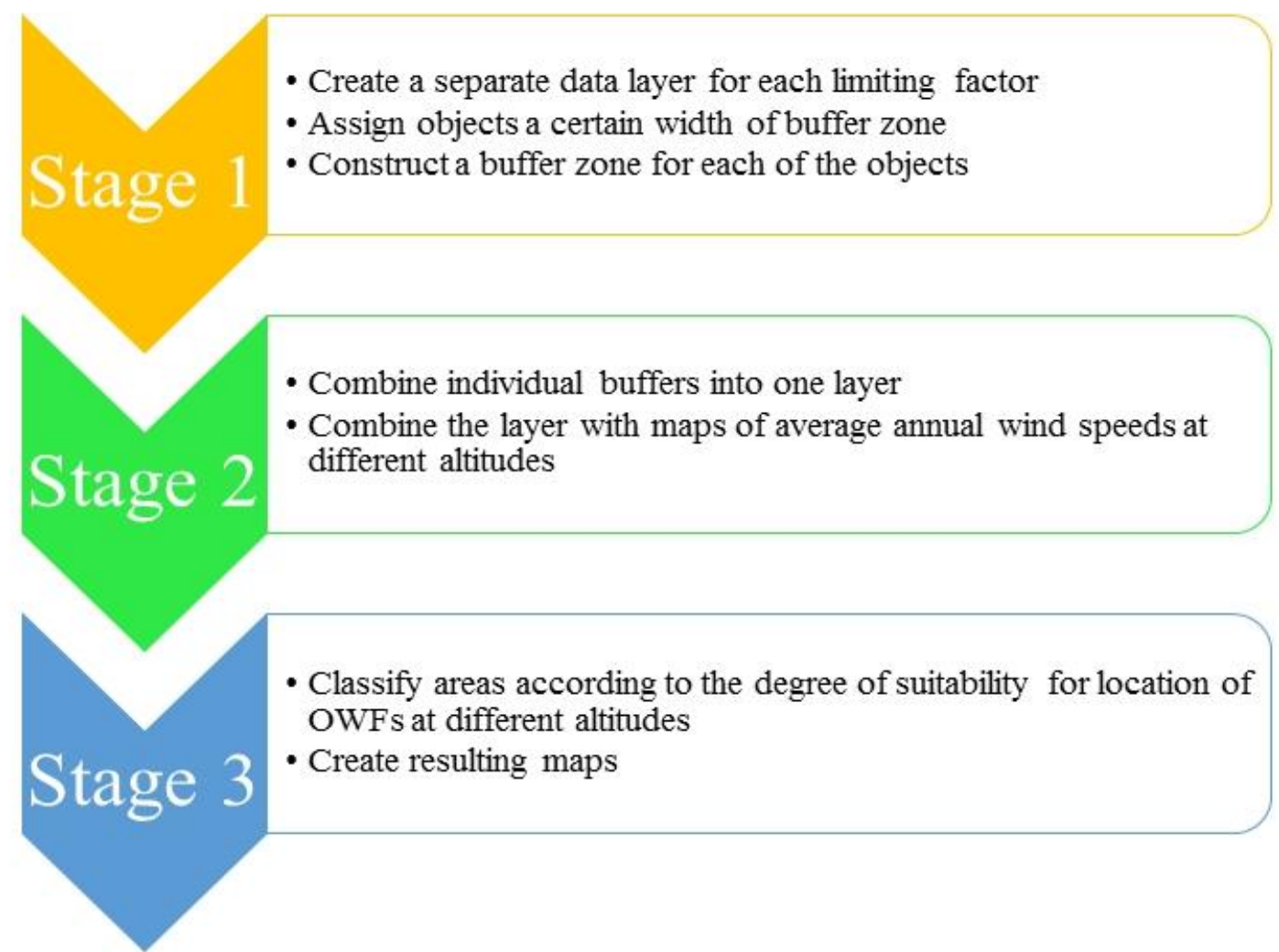

Fig. 3. Modeling of limiting factors of the location of OWFs with the selection of promising areas

maps of average annual wind speeds at different altitudes for our water area. The output surface contains the attributes of the previous layers. The transformation of the buffer into a single polygonal object was carried out using the Merge tool, and then, with the Erase tool, a part of the buffer zone extending beyond the waters of the Sea of Azov to the land was removed. The result was a solid polygon with buffer zones for settlements, airports and objects of the Natural Reserve Fund. In this way, a picture of water areas suitable or unsuitable for offshore wind turbines was obtained.

The third stage was the classification and creation of the resulting maps. At this stage, the assessment of the suitability of certain areas for the location of OWFs on the basis of wind speed criteria and limiting factors was performed.

Within the Sea of Azov the water area can be divided into three types:

- wind speeds over $8 \mathrm{~m} / \mathrm{s}$, without limiting factors (high degree of suitability for installation of offshore wind turbines),

- wind speeds from 6.1 to $8 \mathrm{~m} / \mathrm{s}$, without limiting factors (medium degree of suitability for installation of offshore wind turbines),

- with limiting factors (not suitable for installation of offshore wind turbines, even at sufficient wind speeds).

Based on this classification and wind speeds at altitudes of 50, 100 and 200 meters, maps of the assessment of the suitability of the Sea of Azov for the location of OWFs have been created.

The lowest wind speeds are recorded at an altitude of $50 \mathrm{~m}$, because, as is known, the force of air friction increases as we approach the surface. At this level, a sector with wind speeds over $8 \mathrm{~m} / \mathrm{s}$ stretches along the northern coast of the sea, its area is $3353 \mathrm{~km}^{2}$. Taking into account all the restrictions, the resulting area with the highest suitability for the installation of OWFs is $3098 \mathrm{~km}^{2}$, that is, decreases by almost $8 \%$ or $255 \mathrm{~km}^{2}$.

For an altitude of $100 \mathrm{~m}$, the most promising zone for the implementation of offshore wind projects has an area of $3156 \mathrm{~km}^{2}$ (although areas with wind speeds over $8 \mathrm{~m} / \mathrm{s}$ are $3562 \mathrm{~km}^{2}$ ). Thus, at this altitude, due to existing restrictions, the area that falls into our field of interest has decreased by almost $11.5 \%$ or $406 \mathrm{~km}^{2}$.

The most effective area for the installation of OWFs at an altitude of $200 \mathrm{~m}$ is $5122 \mathrm{~km}^{2}$. That is, zones with a total area of $1422 \mathrm{~km}^{2}$ or almost $22 \%$ of the initial value are not suitable for offshore wind turbines due to limiting factors (Fig. 4).

Thus, $82.6 \%$ of the area of territorial waters of Ukraine in the Sea of Azov is generally suitable for the installation of OWFs. Since the limiting factors considered in the study do not have a height reference, the area of the most promising sites for offshore wind turbines increases with an altitude, where wind characteristics are better $\left(3098 \mathrm{~km}^{2}-\right.$ for $50 \mathrm{~m}, 3156 \mathrm{~km}^{2}$ - for $100 \mathrm{~m}, 5122 \mathrm{~km}^{2}$ - for 200 $\mathrm{m})$. Hence the logical conclusion that in the Sea of 


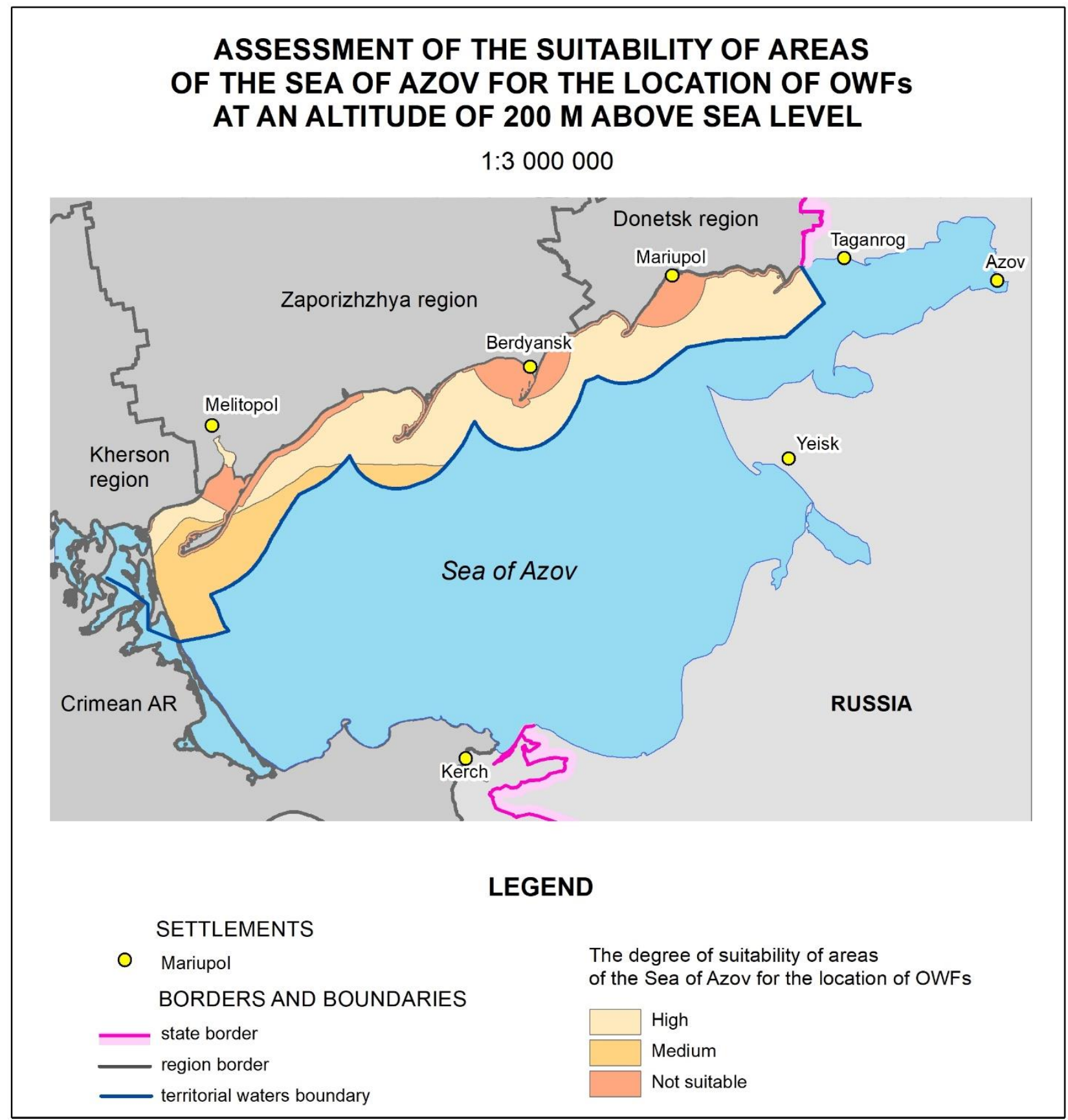

Fig. 4. Assessment of the suitability of areas of the Sea of Azov for the location of OWFs at an altitude of $200 \mathrm{~m}$ above sea level (scale changed)

Azov, from an economic point of view, it is more practical and efficient to install wind turbines with a tower height of more than $100 \mathrm{~m}$.

Conclusions and research perspectives. Our research has shown that the installation of OWFs is appropriate in the waters of the Sea of Azov, because many areas are characterized by average annual wind speeds over $6 \mathrm{~m} / \mathrm{s}$. The most promising areas are the northern and northeastern coasts, where wind speeds at different altitudes range from 8 to $9.3 \mathrm{~m} / \mathrm{s}$, in particular in Taganrog Bay.

The development of offshore wind energy in Ukraine has an international aspect, as the delimitation of the Sea of Azov between Ukraine and the
Russian Federation is not completed, which, given the unpredictability of our eastern neighbour, may hinder the development of this sector of alternative energy.

At altitudes of 50, 100 and $200 \mathrm{~m}$, under the action of limiting factors, the most promising for offshore wind energy areas are reduced by $8-22 \%$. As considered in the study limiting factors (territorial waters, protected areas, settlements and airports) have identical influence regardless of an altitude, it is more effective to install wind turbines with a tower height of more than $100 \mathrm{~m}$ in the waters of the Sea of Azov. 
The final conclusion on the effectiveness of wind turbines in the Sea of Azov requires interdisciplinary research involving ecologists, economists, biologists, sociologists and other experts and landscape-technological assessment of the area at the local level.

\section{Bibliography}

1. Агапова О.Л. Дрібномасштабне картографування з метою планування розвитку альтернативної енергетики в Україні / О.Л. Агапова // Часопис картографії. - 2016. - Bип. 14. - С. 6-21.

2. Величко С.А. Природно-ресурсне забезпечення гібридних геліо-вітроенергетичних систем (в межах рівнинної території України): Автореф. дис... канд. геогр. наук: 11.00.11 / С.А. Величко; Харк. наи. ун-т імені В.Н. Каразіна. - Харків, 2006. - 20 с.

3. Водний кодекс Украӥни : станом на 1 вересня 2012 р. / Верховна Рада Украӥни. - Офіи. вид. - Київ : Парламентське видавництво, 2012. - 246 с.

4. Волковая О.О. Моделювання вітрового потенціалу локальної ділянки Лісостепу для потреб вітроенергетики з використанням ГІС-технологій / О.О. Волковая, О.С. Третьяков, І.Г. Черваньов // Український географічний журнал. - 2015. - № 4. - C. 10-16. https://doi.org/10.15407/ugz2015.04.010

5. Електроенергетичний потенціал відновлюваних джерел енергії України [Електронний ресурс] // Iнститут відновлюваної енергетики НАН Украӥни. - Режим доступу: https://www.ive.org.ua/wpcontent/uploads/kudrya2020-1.pdf

6. Енергетична стратегія України на період до 2035 року «Безпека, енергоефективність, конкурентоспроможність». - Режим доступу: http://mpe.kmu.gov.ua/minugol/control/uk/doccatalog/list? currDir=50358

7. Кудря С.О. Аналітичний огляд оновлених оиінок щзодо перспектив розвитку вітроенергетики / С.О. Кудря, Б.Г. Тучинський, І.В. Іванченко // Відновлювана енергетика. - 2019. - №3. - C.42-47. https://doi.org/10.36296/1819-8058.2019.3(58).42-47

8. Матвєєв В.В. Сучасний етап і перспективи розвитку вітрової енергетики в офиорних зонах України / В.В. Матвєєв, О.С. Шевцьова // Студентські наукові студії. - 2013. - Bun. 4 (35). - С. 55-60.

9. Нараєвський С.В. Порівняльна характеристика ефективності роботи вітрової енергетики у провідних країнах світу та Украӥні / С.В. Нараєвський // Економіка та держава. - 2014. - №5. - С. 85-87.

10. Некос А.Н. Застосування геоінформаційних систем при виріменні завдань просторового планування вітроенергетики / А.Н. Некос, Я.С. Молодан // Вісник ХНУ імені В. Н. Каразіна. Серія «Екологія». - 2014. - Вип. 10 (№1104). - C. 134-141.

11. Очінка впливу кліматичних змін на галузі економіки України: монографія / С.М. Степаненко, А.М. Польовий, С.П. Школьний (та ін.); за ред. С.М. Степаненка, А.М. Польового. - Одеса : Екологія, 2011. - C. 195-197.

12. Попович Н. Перспективи розвитку офиорної вітроенергетики у прибережній зоні Азовського моря / Н. Попович, Д. Джим, О. Агапова // Проблеми безперервної географічної освіти і картографії. - 2019. Bun. 30. - C. 6-14. https://doi.org/10.26565/2075-1893-2019-30-01

13.Потоиький Д.В. Перспективи розвитку вітроенергетики Украӥни / Д.В. Потоиький, Л.В. Шилкова, А.М. Маслєнніков // Вісник НТУ «ХПІ». - 2014. - №38 (1081). - C. 138-145.

14. Расчёт мощности ветрогенератора [Електронний ресурс]. - Режим доступу: https://ensat.ru/help/7/13/38.html

15. Рафикова Ю.Ю. Использование ГИС-технологий в области возобновляемой энергетики: зарубежный и отечественный опыт / Ю.Ю. Рафикова, С.В. Киселева, Л.В. Нефедова // Альтернативная энергетика и экология. - 2014. - № 12. - С. 96-106.

16. Руденко Л.Г. Географія: актуалізація на тлі світових трендів / Л.Г. Руденко, С.О. Маруняк, І.Г. Черваньов // Український географічний журнал. - 2018. - №2 (102). - C. 17-25. https://doi.org/10.15407/ugz2018.02.017

17. Світовий прорив офшорної вітроенергетики [Електронний ресурс] // Українська вітроенергетична асоиіаиія. - Режим доступу : http://uwea.com.ua/ua/article/mirovoj-proryv-offshornoj-vetroenergetiki/

18. Солідор Н.А. Інновачійні підходи до отримання електроенергї̈ нетрадичійними методами / Н.А. Солідор // Вісник Приазовського державного технічного університету : зб. наук. пращьь. - Маріуполь, 2017. - Buп. 34. C. 89-96.

19. Цілі сталого розвитку: Украӥна [Електронний ресурс] : національна доповідь 2017. - Режим доступу: http://www.un.org.ua/images/SDGs_NationalReportUA

20. A Global Overview of Renewable Energy Sources (AGORES). Global Warming and Climate Change [Електронний pecypc]. - Режим достуny: http://www.agores.org/General/Climatehome.htm

21. Adedipe O. A Review of Onshore and Offshore Wind Energy Potential in Nigeria / O. Adedipe, M. S. Abolarin, R. O. Mamman. - IOP Conf. Series: Materials Science and Engineering, 2018. - Vol. 413 (1). - P. 12-19. https://doi.org/10.1088/1757-899X/413/1/012039

22. ArcGIS for Desktop: Spline [Електронний ресурс]. - Режим доступy: https://desktop.arcgis.com/ru/arcmap/ 10.3/tools/spatial-analyst-toolbox/spline.htm

23. Global Atlas for Renewable Energy [Електронний ресурс]. - Режим доступy : https://irena.masdar.ac.ae

24. Global Offshore Wind Market Set to Grow Sixfold by 2030 [Електронний pecypc] // BloombergNEF. - Pежим docmyny : https://about.bnef.com/blog/global-offshore-wind-market-set-to-grow-sixfold-by-2030 
25. Improved Offshore Wind Resource Assessment in Global Climate Stabilization Scenarios [Електронний ресурс] // NREL. - 2012. - 29 p. - Pежuм docmyny: https://www.nrel.gov/docs/fy13osti/55049.pdf. https://dx.doi.org/10.2172/1055364

26. Mahdy M. Offshore Wind Energy Potential Around the East Coast of the Red Sea, KSA / M. Mahdy, A. S. Bahaj, A. S. Alghamdi // ISES Solar World Conference 2017 Proceedings. - Режим доступy: http://proceedings.ises.org/paper/swc2017/swc2017-0247-Mahdy.pdf. https://doi.org/10.18086/swc.2017.38.02

27. Offshore Wind Leasing Round 4 signals major vote of confidence in the UK's green есопоту [Електронний реcypc] // The Crown Estate. - Режuм достуny: https://www.thecrownestate.co.uk/en-gb/media-andinsights/news/2021-offshore-wind-leasing-round-4-signals-major-vote-of-confidence-in-the-uk-s-green-economy/

28. Poland starts talks on 10GW-plus offshore plans [Електронний ресурс] // Windpower Monthly. - Peжим docmyny : https://www.windpowermonthly.com/article/1671012/poland-starts-talks-10gw-plus-offshore-plans

29. Record 6.1 GW of new offshore wind capacity installed globally in 2019 [Електронний ресурс] // WindTECH International. - Режим доcmyny: https://www.windtech-international.com/industry-news/record-6-1gw-of-newoffshore-wind-capacity-installed-globally-in-2019

30. Rodriguez H.M. Preliminary Cost Assessment for Offshore Wind Energy in Puerto Rico / H.M. Rodriguez, G. Carbajal, E. Romero. - Universidad del Turabo, 2015. - P. 5-10. http://dx.doi.org/10.18687/LACCEI2015.1.1.186

31. Salvacao N. Assessing the Offshore Wind Energy Potential Along the Coasts of Portugal and Galicia / N. Salvacao, M. Bernardino, S. C. Guedes // Developments in Maritime Transportation and Exploitation of Sea Resources. 2014. - P. 995-1002.

32. Tavner P. Offshore Wind Turbines. Reliability, availability and maintenance / P. Tavner. - The Institution of Engineering and Technology, 2012. - 296 p. https://doi.org/10.1049/PBRN013E

33. Wind energy in Europe 2020. Statistics and the outlook for 2021-2025 [Електронний ресурс] // Wind Europe. Режим достуny: https://windeurope.org/data-and-analysis/product/wind-energy-in-europe-in-2020-trends-andstatistics/

Submitted April 04, 2021

Accepted April 28, 2021

Authors Contribution: Authors contributed to this work equally.

UDC 911.9:620.92(262.54)

Nataliia Popovych,

$\mathrm{PhD}$ (Geography), Associate Professor, Department of Physical Geography and Cartography,

V. N. Karazin Kharkiv National University, 4, Svobody Sq., Kharkiv, 61022, Ukraine, e-mail: n.popovych@physgeo.com, http://orcid.org/0000-0003-4968-6296;

Vilina Peresadko,

DSc (Geography), Professor, Department of Physical Geography and Cartography, V. N. Karazin Kharkiv National University, e-mail: vilinaperesadko@gmail.com, http://orcid.org/0000-0002-2439-2788;

\section{Daria Dzhym,}

Master (Geography), Department of Physical Geography and Cartography,

V. N. Karazin Kharkiv National University,

e-mail:d.dzhim@physgeo.com,https://orcid.org/0000-0002-3823-1942

\section{DEVELOPMENT OF OFFSHORE WIND ENERGY OF UKRAINE IN THE SEA OF AZOV: THE GEOGRAPHICAL ASPECT}

Formulation of the problem. Ukraine's energy sector is import-dependent, and one of the country's sustainable development goals until 2030 is to ensure access to affordable, reliable, sustainable and modern energy sources. The wind potential of the mainland of our country has been thoroughly studied, so the focus of our interest is water areas, which are promising for the development of offshore wind energy. Offshore wind farms in Ukraine could improve the environmental situation and considerably contribute to the decarbonization of domestic energy. That is why the study considers the opportunity of offshore wind farms installation in the Sea of Azov.

Methods. The analysis of literary and cartographic sources has been carried out. Mathematical methods have been used to calculate energy indicators. Using geoinformation modeling, taking into account limiting factors, suitable for the installation of offshore wind farms areas have been identified in the Sea of Azov.

The purpose of the article is to geographically analyze the wind energy potential of the Sea of Azov with further assessment of the suitability of areas for the offshore wind farms location. 
Results. Our research has shown that the installation of offshore wind farms is appropriate in the Sea of Azov, because many areas are characterized by average annual wind speed above 6 meters per second. The most promising areas are the northern and northeastern coasts, where wind speed at different altitudes ranges from 8 to 9.3 meters per second.

At altitudes of 50,100 and $200 \mathrm{~m}$, under the action of limiting factors, the most promising for offshore wind turbines areas are reduced by $8-22 \%$. As considered limiting factors (territorial waters, nature protection objects, settlements and airports) have identical influence regardless of height, it is more effective to install wind turbines with a tower height of more than $100 \mathrm{~m}$ in the waters of the Sea of Azov. Interdisciplinary research is needed for the final answer on the effectiveness of offshore wind turbines in the Sea of Azov.

Scientific novelty and practical significance. The results of the analysis of the wind energy potential of the Sea of Azov have been given, the tendency of its growth from the west to the east has been revealed. Attention has been paid to the method of geoinformation modeling of the location of offshore wind farms taking into account limiting factors. Maps of wind speed, potential of electricity generated by a single wind turbine and suitability of areas of the Sea of Azov for the location of offshore wind farms at an altitude of $200 \mathrm{~m}$ above sea level have been presented. These data can be used by designers of wind energy facilities as a basis for determining the optimal power of wind turbines and the type of energy for a particular area of the Sea of Azov.

Keywords: geographical aspect, offshore wind energy, offshore wind power plant, wind energy potential, the Sea of Azov, Ukraine.

\section{References}

1. Agapova, O. L. (2016). Dribnomasshtabne kartografuvannya z metoyu planuvannya rozvytku al ternaty vnoyi energetyky $v$ Ukrayini [Small-scale mapping for the planning of alternative energy development in Ukraine]. Magazine of Cartography, 14, 6-21 [in Ukrainian].

2. Velychko, S.A. (2006). Pry`rodno-resursne zabezpechennya gibry`dny`x gelio-vitroenergety`chny`x sy`stem (v mezhax rivny`nnoyi tery`toriyi Ukrayiny`) [Natural resources providing for hybrid solar-wind energy systems (in the frontiers of plain territory of Ukraine)]. The thesis for the degree of candidate of geographical sciences on specialty 11.00.11. V.N. Karazin Kharkiv National University, Kharkiv, 20.

3. Water Code of Ukraine: as of September 1, 2012. Verkhovna Rada of Ukraine. Kyiv: Parliamentary Publishing House, 246 [in Ukrainian].

4. Volkovaia, O. O., Tretyakov, O. S., Chervaniov, I. H. (2015). Modelyuvannya vitrovogo potencialu lokal noyi dilyanky Lisostepu dlya potreb vitroenergetyky $z$ vykorystannyam GIS-texnologij [Local forest-steppe area wind potential modeling for the wind energy needs with the use of GIS technology]. Ukrainian Geographical Journal, 4, 10-16 [in Ukrainian]. https://doi.org/10.15407/ugz2015.04.010

5. Elektroenergetychnyj potencial vidnovlyuvany`x dzherel energiyi Ukrayiny [Electricity potential of renewable energy sources of Ukraine]. Institute of Renewable Energy, NASU. Available at: https://www.ive.org.ua/wpcontent/uploads/kudrya2020-1.pdf [in Ukrainian]. - 15.03.2021

6. Energetychna strategiya Ukrayiny na period do 2035 roku «Bezpeka, energoefekty vnist', konkurentospromozhnist'» [Energy strategy of Ukraine to 2035 "Security, energy efficiency, competitiveness"]. Available at : http://mpe.kmu.gov.ua/minugol/control/uk/doccatalog/list?currDir=50358 [in Ukrainian]. - 11.03.2021

7. Kudrya, S. O., Tuchynskyi, B. G., Ivanchenko, I. V. (2019). Anality`chny`j oglyad onovleny`x ocinok shhodo perspekty $v$ rozvy`tku vitroenergety $k y `[$ Analytical review of the updated estimates of the prospects for the development of wind energy]. Renewable Energy, 3, 42-47 [in Ukrainian]. https://doi.org/10.36296/1819-8058.2019.3(58)

8. Matvyeyev, V. V, Shevczova, O. S. (2013). Suchasny`j etap i perspekty`vy` rozvy`tku vitrovoyi energety $k y ` v$ ofshorny`x zonax Ukrayiny` [Current stage and prospects of wind energy development in offshore zones of Ukraine]. Student research studios, 4 (35), 55-60 [in Ukrainian].

9. Naraievs'kyj, S. V. (2014). Porivnyal`na xaraktery`sty`ka efekty`vnosti roboty`vitrovoyi energety`ky`u providny`x krayinax svitu ta Ukrayini [Comparative characterization of the efficiency of wind energy in the leading countries of the world and Ukraine]. Economy and State, 5, 85-87 [in Ukrainian].

10. Nekos, A. N., Molodan, Ia. E. (2014). Zastosuvannya geoinformacijny`x sy`stem pry`vy`rishenni zavdan`prostorovogo planuvannya vitroenergety 'ky`[Geographic information systems application in problem-solving of spatial planning for wind energy]. Visnyk of V. N. Karazin Kharkiv National University. Series Ecology, 10 (1104), 134-141 [in Ukrainian].

11. Ocinka vply`vu klimaty`chny`x zmin na galuzi ekonomiky`Ukrayiny`: monografiya [Assessment of climate change impact in the field of Ukrainian economy: monograph]. Edited by S. M. Stepanenko, A. M. Pol'ovyj. Odessa, Ecology, 2011, 195-197 [in Ukrainian].

12. Popovych, N., Dzhym, D., Agapova, O. (2019). Perspekty`vy`rozvy`tku ofshornoyi vitroenergety`ky`u pry`berezhnij zoni Azovs kogo morya [Prospects for the development of offshore wind power along the coast of the Sea of Azov]. Problems of Continuous Geographic Education and Cartography, 30, 6-14. https://doi.org/10.26565/2075-18932019-30-01 
13. Potocz`ky`j, D. V., Shy`lkova, L.V., Maslyennikov, A.M. (2014). Perspekty`vy`rozvy`tku vitroenergety`ky` Ukrayiny` [Prospects of development of the wind power plants of Ukraine]. Visnyk of National Technical University "Kharkiv Polytechnic Institute», 38 (1081), 138-145 [in Ukrainian].

14. Raschjot moshhnosti vetrogeneratora [Calculation of wind generator power]. - Available at: https://ensat.ru/help/7/13/38.html [in Russian]. - 11.03.2021

15. Rafikova, Y. Y., Kiseleva, S. V., Nefedova, L. V. (2014). Ispol'zovanie GIS-tehnologij v oblasti vozobnovljaemoj jenergetiki: zarubezhnyj i otechestvennyj opyt [The use of GIS technology in the field of renewable energy: international and national experience]. Alternative Energy and Ecology, 12, 96-106 [in Russian].

16. Rudenko, L. H., Maruniak, Eu. O., Chervaniov, I. H. (2018). Geografiya: aktualizaciya na tli svitovy`x trendiv [Geography: updating toward world trends]. Ukrainian Geographical Journal, 2 (102), 17-25 [in Ukrainian]. https://doi.org/10.15407/ugz2018.02.017

17. Svitovy j prory`v of shornoyi vitroenergety `ky [Global breakthrough of offshore wind energy]. Ukrainian Wind Energy Association. Available at: http://uwea.com.ua/ua/article/mirovoj-proryv-offshornoj-vetroenergetiki/ [in Ukrainian]. - 09.03.2021

18. Solidor, N. A. (2017). Innovacijni pidxody` do otry`mannya elektroenergiyi netrady`cijny`my`metodamy`[Innovative approaches to power generation by nontraditional methods]. Bulletin of Priazovskyi State Technical University, 34, 89-96 [in Ukrainian].

19. Cili stalogo rozvy tku: Ukrayina : nacional’na dopovid 2017 [Sustainable Development Goals: Ukraine: National Report 2017]. Available at: http://www.un.org.ua/images/SDGs_NationalReportUA [in Ukrainian]. - 15.03.2021

20. A Global Overview of Renewable Energy Sources (AGORES). Global Warming and Climate Change. Available at : http://www.agores.org/General/Climatehome.htm - 11.03.2021

21. Adedipe, O., Abolarin, M. S., Mamman. R. O. (2018). A Review of Onshore and Offshore Wind Energy Potential in Nigeria. IOP Conf. Series: Materials Science and Engineering, 413 (1), 12-19. https://doi.org/10.1088/1757$\underline{899 X / 413 / 1 / 012039}$

22. ArcGIS for Desktop: Spline. Available at: https://desktop.arcgis.com/ru/arcmap/10.3/tools/spatial-analysttoolbox/spline.htm. - 01.03.2021

23. Global Atlas for Renewable Energy. Available at: https://irena.masdar.ac.ae. - 03.03.2021

24. Global Offshore Wind Market Set to Grow Sixfold by 2030. BloombergNEF. Available at: https://about.bnef.com/blog/global-offshore-wind-market-set-to-grow-sixfold-by-2030. -05.03.2021

25. Improved Offshore Wind Resource Assessment in Global Climate Stabilization Scenarios. (2012). NREL, 29. Available at: https://www.nrel.gov/docs/fy13osti/55049.pdf. - 11.03.2021. https://dx.doi.org/10.2172/1055364

26. Mahdy, M., Bahaj, A. S., Alghamdi, A. S. (2017). Offshore Wind Energy Potential Around the East Coast of the Red Sea, KSA. ISES Solar World Conference 2017 Proceedings. Available at: http://proceedings.ises.org/paper/ swc2017/swc2017-0247-Mahdy.pdf. - 03.03.2021. https://doi.org/10.18086/swc.2017.38.02

27. Offshore Wind Leasing Round 4 signals major vote of confidence in the UK's green economy. The Crown Estate. Available at: https://www.thecrownestate.co.uk/en-gb/media-and-insights/news/2021-offshore-wind-leasing-round4-signals-major-vote-of-confidence-in-the-uk-s-green-economy/. - 01.03.2021

28. Poland starts talks on 10GW-plus offshore plans. Windpower Monthly. Available at : https://www.windpowermonthly.com/article/1671012/poland-starts-talks-10gw-plus-offshore-plans. - 05.03.2021

29. Record $6.1 \mathrm{GW}$ of new offshore wind capacity installed globally in 2019. WindTECH International. Available at: https://www.windtech-international.com/industry-news/record-6-1gw-of-new-offshore-wind-capacity-installedglobally-in-2019. - 05.03.2021

30. Rodriguez, H. M., Carbajal, G., Romero, E. (2015). Preliminary Cost Assessment for Offshore Wind Energy in Puerto Rico. Universidad del Turabo, 5-10. http://dx.doi.org/10.18687/LACCEI2015.1.1.186

31. Salvacao, N., Bernardino, M., Guedes, S. C. (2014). Assessing the Offshore Wind Energy Potential Along the Coasts of Portugal and Galicia. Developments in Maritime Transportation and Exploitation of Sea Resources, $995-1002$.

32. Tavner, P. (2012). Offshore Wind Turbines. Reliability, availability and maintenance The Institution of Engineering and Technology, 296. https://doi.org/10.1049/PBRN013E

33. Wind energy in Europe 2020. Statistics and the outlook for 2021-2025. Wind Europe. Available at: https://windeurope.org/data-and-analysis/product/wind-energy-in-europe-in-2020-trends-and-statistics/. - 03.03.2021 